\title{
ГИДРОХИМИЧЕСКИЙ СОСТАВ И РЕДКОЗЕМЕЛЬНЫЕ ЭЛЕМЕНТЫ В ПОЛИГОНАЛЬНО-ЖИЛЬНЫХ ЛЬДАХ КЛЮЧЕВЫХ РАЙОНОВ КРИОЛИТОЗОНЫ КАРСКОГО РЕГИОНА
}

\author{
Бутаков Владислав Игоревич 1 , \\ vladbutakov@yahoo.com
}

\author{
Слагода Елена Адольфовна2,3,1, \\ eslagoda@ikz.ru
}

Тихонравова Яна Витальевна4,2, tikh-jana@yandex.ru

1 Тюменский индустриальный университет, Россия, 625000, г. Тюмень, ул. Володарского, 38.

2 Институт криоссреры Земли ТюмНЦ СО РАН, Россия, 625000, г. Тюмень, ул. Малыгина, 86.

3 Тюменский государственный университет, Россия, 625003, г. Тюмень, ул. Володарского, 6.

4 Институт мерзлотоведения им. П.И. Мельникова СО РАН, Россия, 677010, г. Якутск, ул. Мерзлотная, 36

5 Лимнологический институт СО РАН, Россия, 664033, г. Иркутск, ул. Улан-Баторская, 3.

\author{
Опокина Ольга Леонидовна 2,1 \\ opokina@ikz.ru
}

\author{
Томберг Ирина Викторовна 5 , \\ kaktus@lin.irk.ru
}
Жученко Наталья Альбертовна 5 , zhna@lin.irk.ru

Актуальность исследования. Информация о составе, льдистости и геохимических особенностях мерзльх пород необходима при освоении нефртегазоконденсатных месторождений Ямала, Гыдана и Таймыра. Среди фракторов, определяющих экологию тундровых ландшафтов криолитозоны, большое значение имеют подземные льды, в том числе полигонально-жильнье, и последствия их вытаивания. Гидрохимический состав и содержание редкоземельных элементов в сингенетических жилах фиксируют информацию об источниках влаги и условиях, при которых происходило их формирование. Соотношение основных ионов и распределение редкоземельных элементов в растворе может быть использовано для оценки влияния на состав льда атмосфеерных осадков, морских и вулканических аэрозолей, антропогенного загрязнения.

Цель: выявить источники поступления химических элементов и оценить влияние типа льдовыделения на гидрохимический состав и распределение редкоземельных элементов в различных генетических типах льда - полигонально-жильном, морском, озерном и фирновом льдах.

объекты: полигонально-жильный лед, вмещающие его отложения, сезонные льды, поверхностные воды, отобранные в экспедициях ИКЗ ТюмНЦ СО РАН в 2009-2014 ге.

Методы исследования химического состава: масс-спектрометрия с индуктивно связанной плазмой, атомноабсорбционная спектрометрия, эмиссионная фотометрия, хроматография.

Результаты. Установлено, что на химический состав полигонально-жильных льдов, изученных в прибрежной зоне ключевых участков о. Бельй, о. Сибирякова, Западного Ямала и Западного Таймыра, имели влияние морские и континентальные аэрозоли. Сингенетические полигонально-жильные льды, пресные и ультрапресные по минерализации, сформированы при промерзании талых вод, которые содержат сорбированные снегом морские аэрозоли - взвешенные в атмосфрере твердые и жидкие частицы. Полигонально-жильные льды в удаленном от моря районе оз. Сохонто не имеют признаков морского влияния по соотношению основных ионов. Полигонально-жильные льды с минеральными включениями формировались не только за счет талых снеговых вод с аэрозолями континентального происхождения, но и за счет надмерзлотных вод. В полигонально-жильных льдах выявлено увеличение содержаний лантаноидов в водорастворимой форме по сравнению с кларковыми значениями и современными поверхностными льдами. По цериевой аномалии в большинстве изученных сингенетических ледяных жил подтверждается участие морских аэрозолей. По распределениям редкоземельных элементов выявлено характерное для полигонально-жильных льдов соотношение легких и тяжелых редкоземельных элементов равное 0,9, и соотношение лантана к остальным лантаноидам, равное 0,2. Морской лед наследует минерализацию и состав морской воды. Озерный лед различается по глубине и отражает сезонное изменение гидрохимического состава при ледоставе и повышение концентрации морских аэрозолей в снеге, перекрывающем озерный лед. Фирновый лед полярного Урала имеет очень низкую минерализацию, в нем отсутствуют примеси морского аэрозоля. В полигонально-жильных льдах голоценового и неоплейстоценового возраста реализован природный механизм накопления редкоземельных элементов в водорастворимой форме в комплексе с железом, торием и иттрием. Вытаивание ледяных жил может приводить к поступлению редкоземельных элементов в поверхностные воды.

\section{Ключевые слова:}

Полигонально-жильный лед, гидрохимия льда, редкоземельные элементы, геохимия отложений, криогенное концентрирование, кларк гидросферы. 


\section{Введение}

Химический состав природных льдов определяется присутствием в нем минеральных и органических веществ, растворенных газов [1]. Наличие этих компонентов в водном растворе обусловлено целым рядом протекающих в разных природных условиях физических, физико-химических, криогенных, геологических и биологических процессов. Геокриологические исследования включают изучение гидрохимического состава многолетнемерзлых пород и подземных льдов [2]. Водорастворимые соли в многолетнемерзлых породах и льдах при диссоциации образуют главные ионы $\mathrm{Cl}^{-}, \mathrm{SO}_{4}{ }^{2-}, \mathrm{HCO}_{3}{ }^{-}, \mathrm{Na}^{+}, \mathrm{K}^{+}, \mathrm{Ca}^{2+}, \mathrm{Mg}^{2+}$ [3]. Анализ распределения главных ионов в растворе позволяет определить возможный источник воды, участвовавшей в льдообразовании, а также закономерности криогенной концентрации при формировании льдов [4]. Установлено, что при сингенетическом формировании полигонально-жильных льдов основным источником вод являются атмосферные осадки [5]. На Западном Ямале, Западном Таймыре, островах Белый и Сибирякова в Карском море изучены строение, генезис и химический состав подземных льдов, в том числе полигонально-жильных льдов, установлена их связь с генезисом отложений и с воздействием морских вод на состав ледяных жил, сформированных в приливной зоне [6-8]. В последние годы, в связи с интересом к экологическим проблемам Арктики, началось изучение микрокомпонентов, в частности редкоземельных элементов, в составе атмосферных осадков и поверхностных вод. Данные об их распределении в подземных льдах в публикациях немногочисленны. Авторы указывают на связь химического состава пластовых льдов с составом исходной воды и с условиями преобразования при переходе элементов из породы в воду и далее концентрированием солей в подземных водах при промерзании [9]. Определены спектры содержания редкоземельных металлов для пластовых льдов Новосибирских островов [10]. Основным источником редкоземельных элементов в полигонально-жильных льдах могут являться примеси в атмосферных зимних осадках, в том числе антропогенные, морские и вулканические аэрозоли. Кроме того, выявлено, что в составе полигональножильного льда могут участвовать сегрегационный и термокарстово-пещерный лед [11]. Основным источником для образования сегрегационного льда является внутригрунтовая слабосвязанная вода, для термокарстово-полостного льда - поверхностная вода [12]. $\mathrm{C}$ учетом этого в формировании полигональножильного льда могут участвовать вещества, поступавшие вместе с грунтовой влагой и поверхностными водами [13]. Участие поверхностных и морских вод можно установить по основным ионам [14], а участие атмосферных аэрозолей или грунтовой влаги - по распределению редкоземельных элементов в составе полигонально-жильного льда [10].

\section{Методы исследований, математической обработки и интерпретации химического состава}

Пробы для геохимических исследований были отобраны в виде монолитов льда и фильтрованной воды, хранившихся в мерзлом состоянии до проведения анализов. Общий химический и микрокомпонентный анализ монолитов и расплавов льда выполнен в Лаборатории гидрохимии и химии атмосферы Лимнологического института СО РАН, г. Иркутск. Для химического анализа монолиты льда были зачищены, расплавлены и дополнительно отфильтрованы через поликарбонатные фильтры с диаметром пор 0,45 мкм. Основные катионы в расплавах льда и водной вытяжке из отложений $\left(\mathrm{Na}^{+}, \mathrm{K}^{+}, \mathrm{Ca}^{2+}, \mathrm{Mg}^{2+}\right)$ измеряли методом атомной абсорбции (AAS-30, Zeiss Jena, Germany), анионы $\left(\mathrm{SO}_{4}{ }^{2-}, \mathrm{NO}_{3}{ }^{-}, \mathrm{Cl}^{-}\right)$- методом жидкостной хроматографии (Миллихром А-02, Эконова, Россия), гидрокарбонаты $\left(\mathrm{HCO}_{3}^{-}\right)$- потенциометрическим титрованием. Для определения валового состава взвеси, отфильтрованной из расплавов льда, минеральный остаток разлагают смесью концентрированных азотной и плавиковой кислот с ультразвуковым воздействием и нагреванием для перехода минеральных веществ в раствор. Элементный анализ взвеси, воды, расплавов льда и ацетатно-аммонийной вытяжки из отложений был выполнен на квадрупольном масс-спектрометре Agilent 7500се фирмы Agilent Technologies Inc.

Математическая обработка количественных характеристик химического состава включала составление базы данных гидрохимического и элементного состава проб и разработку программы анализа результатов исследований образцов разных типов льда (полигонально-жильного, морского, озерного), вмещающих отложений и взвеси из льда. Массив количественных характеристик химического состава был разделен на группы по районам исследований, по количеству минеральной взвеси во льду, по генезису и возрасту вмещающих отложений методом корреляционного анализа [15]. Для оценки величины минерализации льдов использована классификация, предложенная Ю.К. Васильчуком [16]. При составлении наименования по гидрохимическому типу воды учитывали анионы и катионы, содержание которых составляет более $20 \%$ от суммы миллимолярных концентраций, перечисление ионов производили в порядке возрастания концентраций компонентов - от меньшего значения к большему. Для определения источника воды используют соотношения компонентов. Однако не существует однозначных интерпретаций соотношений главных ионов, нужны дополнительные показатели для определения источников поступления компонентов. Такими показателями могут быть концентрации редкоземельных элементов (РЗЭ) (таблица). 
Известия Томского политехнического университета. Инжиниринг георесурсов. 2020. Т. 331. № 2. 78-91

Бутаков В.И. и др. Гидрохимический состав и редкоземельные элементы в полигонально-жильных льдах ключевых ...

Таблица. Соотношения химических элементов для водных сред

Table. $\quad$ Chemical elements correlation in water environments

\begin{tabular}{|c|c|c|}
\hline $\begin{array}{l}\text { Источник компонента } \\
\text { Component source }\end{array}$ & $\begin{array}{c}\text { Процесс поступления и преобразования компонента } \\
\text { Component receipt and transformation }\end{array}$ & $\begin{array}{c}\text { Преобладающие ионы и соотношения компонентов } \\
\text { Dominant ions and component ratios }\end{array}$ \\
\hline \multirow{3}{*}{$\begin{array}{l}\text { Атмосферный аэрозоль } \\
\text { арктического региона } \\
\text { Atmospheric aerosol of } \\
\text { the arctic region [14] }\end{array}$} & \multirow[t]{2}{*}{$\begin{array}{l}\text { Формирование аэрозоля над поверхностью моря } \\
\text { Aerosol formation over the sea surface }\end{array}$} & $\begin{array}{l}\text { Преобладающие ионы/Dominant ions }-\mathrm{Na}^{+}, \mathrm{Cl}^{-} \text {, } \\
\mathrm{SO}_{4}^{2-}\end{array}$ \\
\hline & & $\begin{array}{l}\text { Корреляция пар ионов/Correlation of ion pairs: } \\
\mathrm{NH}_{4}^{+} / \mathrm{SO}_{4}{ }^{2-}, \mathrm{Na}^{+} / \mathrm{Cl}^{-}, \mathrm{Mg}^{2+} / \mathrm{Cl}^{-}, \mathrm{Ca}^{2+} / \mathrm{NO}_{3}^{-} \\
\end{array}$ \\
\hline & $\begin{array}{l}\text { Летом в составе аэрозоля отражен процесс выветри- } \\
\text { вания пород } \\
\text { Aerosol composition reflects rock weathering in summer }\end{array}$ & Преобладающий ион/Dominant ion $-\mathrm{Ca}^{2+}$ \\
\hline $\begin{array}{l}\text { Снег } \\
\text { Snow [10] }\end{array}$ & $\begin{array}{l}\text { В процессе выветривания в состав снега попадают } \\
\text { большие количества коллоидной взвеси } \\
\text { During weathering the snow contains colloidal } \\
\text { suspension large amounts }\end{array}$ & $\begin{array}{l}\text { Высокое содержание/High content } \mathrm{Cl}^{-}, \mathrm{SO}_{4}{ }^{2-} \\
\text { Се }{ }_{\text {an }}=0,80 \\
\text { Превышение содержания } \mathrm{La}, \mathrm{Ce}, \mathrm{Nd}, \mathrm{Sm}, \mathrm{Gd}, \mathrm{Dy}, \\
\text { Yb относительно кларковых значений для речной } \\
\text { воды более чем в } 2 \text { раза } \\
\text { Exceeding the content of } \mathrm{La}, \mathrm{Ce}, \mathrm{Nd}, \mathrm{Sm}, \mathrm{Gd}, \mathrm{Dy}, \\
\text { Yb relative to the clark values for river water by more } \\
\text { than } 2 \text { times }\end{array}$ \\
\hline \multirow[t]{2}{*}{$\begin{array}{l}\text { Тундровые озера } \\
\text { Tundra lakes [17] }\end{array}$} & $\begin{array}{l}\text { Растворение и выщелачивание осадочных пород } \\
\text { Dissolution and leaching of sedimentary rocks }\end{array}$ & $\left(\mathrm{Ca}^{2+}+\mathrm{Mg}^{2+}\right) / \mathrm{HCO}_{3}^{-}>1$ \\
\hline & $\begin{array}{l}\text { Поступление хлоридов из пород } \\
\text { Receipt of chlorides from soils }\end{array}$ & $\mathrm{Cl}^{-} / \mathrm{Na}^{+}>1,14$ \\
\hline $\begin{array}{l}\text { Речная вода } \\
\text { River water [10] }\end{array}$ & $\begin{array}{l}\text { Содержание РЗЭ отражает состав пород бассейна и } \\
\text { атмосферных осадков } \\
\text { REE content reflects rock composition of the river basin } \\
\text { and precipitation }\end{array}$ & $\begin{array}{l}\mathrm{Ce}_{\mathrm{an}}=1,21 \\
\mathrm{Eu}_{\mathrm{an}}=0,98 \\
\text { Превышение содержания La, Ce, Nd, Sm, Eu, Gd, } \\
\mathrm{Dy,} \mathrm{Er,} \mathrm{Yb} \mathrm{относительно} \mathrm{кларковых} \mathrm{значений} \mathrm{для} \\
\text { речной воды более чем в } 5 \text { раз } \\
\text { Exceeding the content of La, Ce, Nd, Sm, Eu, Gd, } \\
\text { Dy, Er, Yb relative to clark values for river water by } \\
\text { more than } 5 \text { times }\end{array}$ \\
\hline $\begin{array}{l}\text { Морская вода } \\
\text { Sea water }[18,19]\end{array}$ & $\begin{array}{l}\text { Формирование металлоносных осадков } \\
\text { Formation of metal-bearing sediments }\end{array}$ & $\begin{array}{l}\mathrm{Ce}_{\text {an }}<1 \\
(\text { ЛРЗЭ/ТРЗЭ) })^{\mathrm{NASC}}<1\end{array}$ \\
\hline $\begin{array}{l}\text { Полигонально-жильный } \\
\text { лед (о. Новая Сибирь) } \\
\text { Ice wedge (New Siberia } \\
\text { island) [10] }\end{array}$ & $\begin{array}{l}\text { Формирование льда из атмосферных осадков } \\
\text { Ice formation from atmospheric precipitation }\end{array}$ & $\begin{array}{l}\mathrm{Ce}_{\mathrm{an}}=0,97 \\
\mathrm{Eu}_{\mathrm{an}}=2,37 \\
\mathrm{Na}^{+} / \mathrm{Cl}^{-}=1,35 \ldots 1,61 \\
\text { Превышение содержания La, Ce, Nd, Sm, Eu, Gd, } \\
\mathrm{Dy}, \mathrm{Er}, \mathrm{Yb} \text { относительно кларковых значений для } \\
\text { речной воды более чем в } 15 \text { раз } \\
\text { Exceeding the content of } \mathrm{La}, \mathrm{Ce}, \mathrm{Nd}, \mathrm{Sm}, \mathrm{Eu}, \mathrm{Gd}, \\
\mathrm{Dy}, \mathrm{Er}, \mathrm{Yb} \text { relative to the clark values for river water } \\
\text { by more than } 15 \text { times }\end{array}$ \\
\hline $\begin{array}{l}\text { Полигонально-жильный } \\
\text { лед (Западный Ямал) } \\
\text { Polygonal ice wedge } \\
\text { (Western Yamal) [20] } \\
\end{array}$ & $\begin{array}{l}\text { Поступление компонентов из атмосферных осадков, } \\
\text { содержащих морские соли } \\
\text { Receipt of components from precipitation containing } \\
\text { marine salts }\end{array}$ & $\begin{array}{l}\left(\mathrm{Na}^{+}+\mathrm{K}^{+}\right) / \mathrm{Cl}^{-}=0,9 \\
\mathrm{Mg}^{++} \mathrm{Cl}^{-}=0,2\end{array}$ \\
\hline $\begin{array}{l}\text { Шлировый лед } \\
\text { Lens ice [10] }\end{array}$ & $\begin{array}{l}\text { Поступление компонентов из осадочных пород } \\
\text { Receipt of components from sedimentary rocks }\end{array}$ & $\begin{array}{l}\mathrm{Na}^{+} / \mathrm{Cl}^{-}=6,95 \\
\text { Превышение содержания La, Ce, Nd, Sm, Eu, Gd, } \\
\text { Dy, Er, Yb относительно кларковых значений для } \\
\text { речной воды более чем в } 8 \text { ра3 } \\
\text { Exceeding the content of La, Ce, Nd, Sm, Eu, Gd, } \\
\text { Dy, Er, Yb relative to Clarke values for river water } \\
\text { by more than } 8 \text { times }\end{array}$ \\
\hline $\begin{array}{l}\text { Пластовые льды } \\
\text { Massive ground ice [10] }\end{array}$ & $\begin{array}{l}\text { Поступление компонентов из морских вод и осадоч- } \\
\text { ных пород } \\
\text { Receipt of components from sea water and sedimentary } \\
\text { rocks }\end{array}$ & $\begin{array}{l}\mathrm{Ce}_{\mathrm{an}}<1 \\
\mathrm{Eu}_{\mathrm{an}}<1 \\
\mathrm{Mg}^{2+} / \mathrm{Cl}^{-}=0,11 \ldots 0,60 \\
\mathrm{Na}+/ \mathrm{Cl}^{-}=11,9 \\
\end{array}$ \\
\hline $\begin{array}{l}\text { Текстурообразующие } \\
\text { льды } \\
\text { Texture-forming ice [21] }\end{array}$ & $\begin{array}{l}\text { Поступление компонентов из осадочных пород } \\
\text { Receipt of components from sedimentary rocks }\end{array}$ & \begin{tabular}{|l}
$u_{\text {an }}>1$ \\
$(Л \text { ЗЭЭ/ТРЗЭ) })^{\mathrm{NASC}} \sim 1$ \\
Содержание РЗЭ равно значению кларковых \\
чисел для речной воды \\
The REE content is equal to the value of the Clark \\
numbers for river water
\end{tabular} \\
\hline
\end{tabular}

Для выявления геохимических аномалий проведено сравнение содержания редкоземельных элементов в полигонально-жильных и сезонных льдах с кларками этих элементов в речной воде, так как минерализация полигонально-жильных льдов сравнима с минерализацией речной воды. Валовый состав взвеси из льда сравнивали с кларками земной коры, которые служат эталоном пониженных или повышенных кон- центраций и нарушения равновесных отношений между элементами [22].

Распределение РЗЭ в различных водных системах служит индикатором окислительно-восстановительных геохимических процессов $[23,24]$. В общем случае поверхностные и подземные воды могут наследовать состав и особенности распределения РЗЭ от пород или водных масс, с которыми они взаимодействуют 
$[25,26]$. Чтобы выявить закономерности в изменении состава РЗЭ в природных процессах, необходимо исключить влияние неравномерной распространенности четных и нечетных элементов. Для этого применяется метод нормализации составов РЗЭ на состав в хондритах или в сланце. Обычно используются содержания, нормированные на NASC (North American Shale Composite) [27]. Спектры содержаний оценивают по величине цериевой $\left(\mathrm{Ce}_{\mathrm{an}}\right)$, европиевой $\left(\mathrm{Eu}_{\mathrm{an}}\right)$ аномалий и соотношению легких (ЛРЗЭ) и тяжелых (ТРЗЭ) элементов, выраженных как:

$$
\begin{gathered}
\mathrm{Ce}_{\mathrm{an}}=\mathrm{Ce} / \mathrm{Ce}_{\mathrm{NASC}} /\left(2 / 3 \times \mathrm{La} / \mathrm{La}_{\mathrm{NASC}}+1 / 3 \times \mathrm{Nd} / \mathrm{Nd}_{\mathrm{NASC}}\right) ; \\
\mathrm{Eu}_{\mathrm{an}}=2 \times \mathrm{Eu} / \mathrm{Eu}_{\mathrm{NASC}} /\left(\mathrm{Sm} / \mathrm{Sm}_{\mathrm{NASC}}+\mathrm{Gd} / \mathrm{Gd}_{\mathrm{NASC}}\right) ; \\
(Л \mathrm{~J} 3 Э / \mathrm{TP} 3 Э)^{\mathrm{NASC}}=\left(\mathrm{La} / \mathrm{La}_{\mathrm{NASC}}+2 \times \mathrm{Pr} / \mathrm{Pr}_{\mathrm{NASC}}+\mathrm{Nd} / \mathrm{Nd}_{\mathrm{NASC}}\right) / \\
/\left(\mathrm{Er} / \mathrm{Er}_{\mathrm{NASC}}+\mathrm{Tm} / \mathrm{Tm}_{\mathrm{NASC}}+\mathrm{Yb} / \mathrm{Yb}_{\mathrm{NASC}}+\mathrm{Lu} / \mathrm{Lu}_{\mathrm{NASC}}\right)[18,28] .
\end{gathered}
$$

Отрицательной называется аномалия, если ее численное значение меньше единицы, положительной если ее численное значение больше единицы. Соотношения основных ионов и редкоземельных элементов являются показателями обстановок формирования осадочных пород и подземных льдов (табл. 1).

\section{Район и объекты исследований}

Комплексные исследования многолетнемерзлых толщ в Карском регионе в 2008-2014 гг. включали изучение состава, строения отложений и геохимических особенностей подземного льда, наземных морского и озерного льда, поверхностных вод на ключевых участках. Исследования геохимических особенностей и микроэлементов в составе полигонально-жильных льдов проведены в районах мыса Марре-Сале (Западный Ямал), 03. Сохонто и р. Юрибей (Центральный Ямал), о. Белый, о. Сибирякова, пос. Диксон и мыс Кареповский (Западный Таймыр) (рис. 1). Климатические условия арктической зоны с продолжительной холодной зимой, коротким прохладным летом, небольшим количеством осадков 400 мм/год и преобладающим западным направлением ветров [29] обеспечивают сплошное распространение многолетнемерзлых пород и подземных льдов.

В работе проанализирован гидрохимический и микрокомпонентный состав 61 образца, из них: 26 полигонально-жильного льда, 15 - озерного и морского льда, 1 -льда ледника Романтиков (Полярный Урал), 3 - поверхностной воды, 11 - взвеси из полигонально-жильного льда, 5 - вмещающих отложений.

Сингенетические полигонально-жильные льды представлены в разрезах:

- о. Белый - вертикально-полосчатыми за счет пузырьков воздуха льдом жил (рис. 2), которые залегают в прибрежно-морских, субаэральных засоленных песках и супесях [30];

- о. Сибирякова - льдом с минеральными включениями (пробы ОС-2-09) и без минеральных примесей (пробы ОС-5-09) в жилах, залегающих соответственно в песчаных отложениях и супесчаных отложениях с крупными линзами автохтонного торфа [8];
- м. Марре-Сале - льдом с вертикальными минеральными включениями (пробы МС-2А-11) в жилах, залегающих в супесях; современной элементарной жилкой и жильным льдом (пробы в центре и на контакте с породой, MC-2-09), залегающих в супесях, перекрытых торфом [20];

- оз. Сохонто - вертикально-полосчатым льдом с минеральными примесями в жиле, залегающей в слоистых песках, супесях и суглинках с линзами автохтонного торфа [31];

- р. Юрибей - вертикально-полосчатым льдом с примесью минеральных частиц в жилах, залегающих в автохтонном торфе и заторфованных супесях;

- п. Диксон - двумя ярусами жил - белым вертикально-полосчатым за счет пузырьков воздуха льдом (пробы Д-2-09 и Д-3-09) в заторфованных супесях и песках с древесными остатками в днище долины и более древним желтоватым вертикально-полосчатым льдом с пленками мути (пробы Д-1-09); залегающих в делювиальных суглинках на склоне возвышенности, сложенной сланцами, гранитами, гнейсами [8];

- м. Кареповский - вертикально-полосчатым льдом с органическими и минеральными примесями в жилах, залегающих в песках с растительным детритом и супесях с прослоями автохтонного торфа, перекрытых антропогенными отложениями - древесиной и корой со следами рубки.

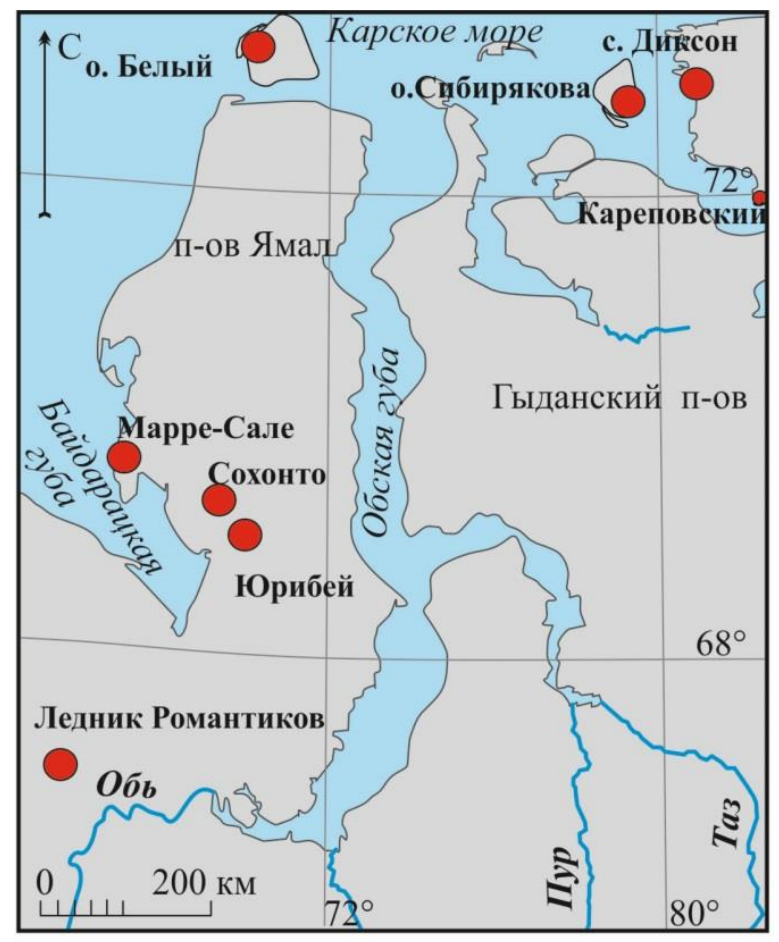

Pис. 1. Ключевые участки исследований геохимии многолетнемёрзлых отложений, полигональножильных льдов и сезонных льдов Карского региона

Fig. 1. Key areas of studying geochemistry of permafrost sediments, polygonal ice wedge and seasonal ice in the Kara region 
Известия Томского политехнического университета. Инжиниринг георесурсов. 2020. Т. 331. № 2. 78-91

Бутаков В.И. и др. Гидрохимический состав и редкоземельные элементы в полигонально-жильных льдах ключевых ...

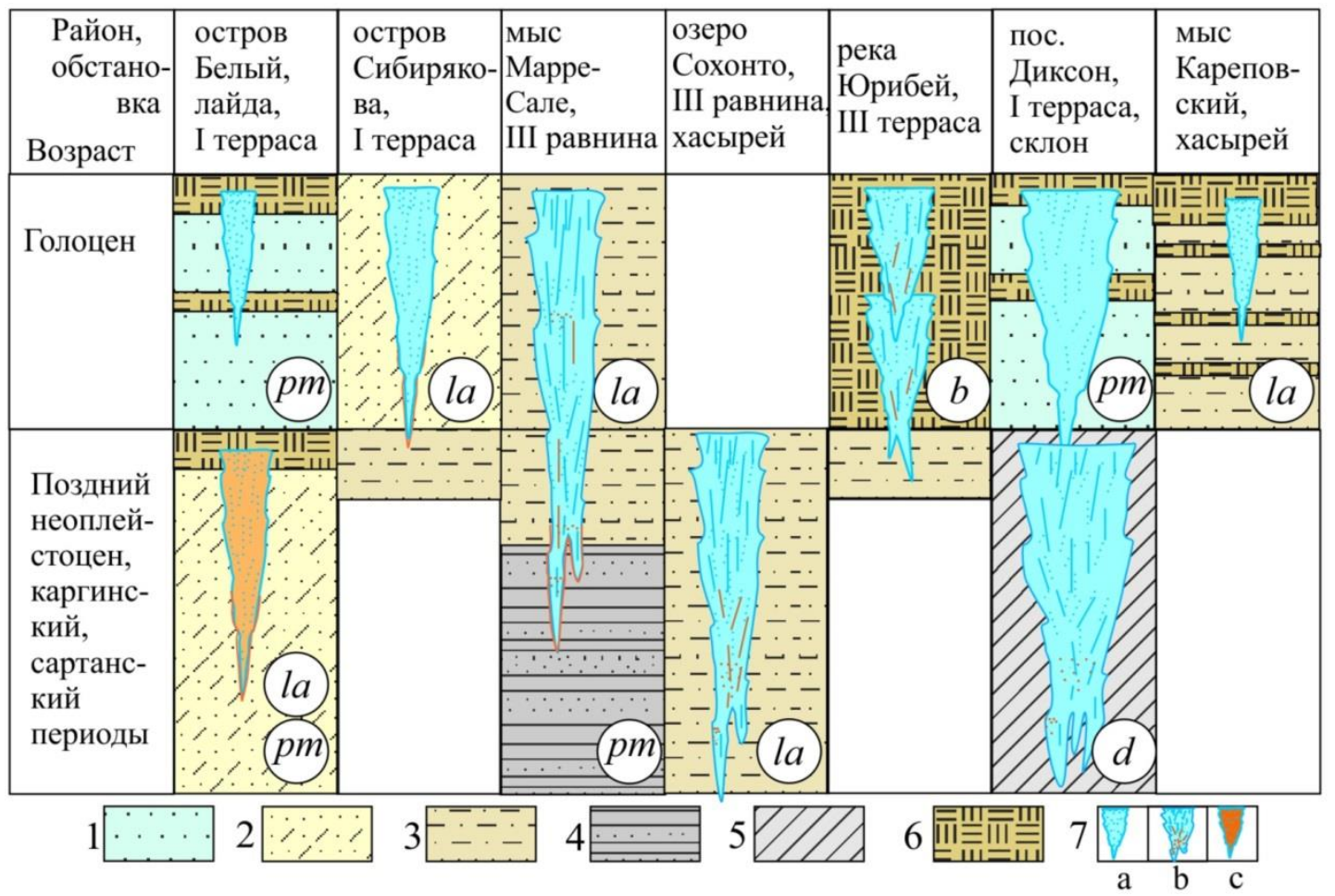

Рис. 2. Условия залегания полигонально-жильных льдов в голоиеновых и верхнеплейстоценовых отложениях Карского региона: 1 - засоленные пески; 2 - пески, супеси с растительными остатками; 3 - супеси с растительными остатками; 4 - слоистые суглинки, супеси засоленные и опресненные; 5 - суглинки пылеватые делювиальные; 6 - торф, биогенные отложения; 7 - ледяные жиль с незначительными органоминеральными включениями (a), ледогрунтовые (b), псевдоморфозы по вытаявщим полигонально-жильным льдам (c). Генезис отложений: $b$ - биогенный; $d$ - делювиальный; la-озерно-аллювиальный; рт - прибрежно-морской

Fig. 2. Occurrence conditions of polygonal ice wedge in Holocene and Upper Pleistocene sediments in the Kara region: 1 saline sands; 2 - sands, sandy loam with plant remains; 3 - sandy loam with plant remains; 4 - stratified loam, sandy loam saline and desalinated; 5 - silty deluvial loam; 6 - peat, biogenic sediments; 7 - ice wedge with minor organic and mineral inclusions $(a)$, ice-ground $(b)$, pseudomorphs of polygonal ice wedge $(c)$. Genesis of deposits: b-biogenic; $d$-deluvial; la-lacustrine-alluvial; pm-coastal-marine

\section{Сезонные льды и поверхностные воды}

Для сравнения химического состава изучены пробы морского, озерного льда в районе м. Марре-Сале; фирнового льда из ледника Романтиков (горный массив Рай-Из на высоте около 800 м); вод из 0з. Сохонто, мелкого озера и ручья в этом районе.

\section{Результаты и их обсуждение}

Полигонально-жильные льды по минерализации ультрапресные и пресные. Льды с низкой минерализации (8..88 мг/л, при среднем значении 33 мг/л) (рис. 3, группа 1) района м. Марре-Сале (МС-2А-11), p. Юрибей, о. Белый, пос. Диксон и м. Кареповский, о. Сибирякова имеют гидрокарбонатно-хлоридный, натриевый гидрохимический состав. Основным источником воды при формировании этих жил служили зимние атмосферные осадки. Хлорид- и натрий-ионы могли поступать из морского аэрозоля, сорбированного снегом [14].

Отношение ионов натрия к хлориду $~ 0,96$ в полигонально-жильных льдах разрезов МС-2А-11 (верхней части), р. Юрибей, о. Белый (нижней части), Д-1-09. Данная зависимость характерна для сингенетических полигонально-жильных льдов района исследований и хорошо коррелирует с соотношением в озерном льду, поверхностной воде и атмосферных осадках [32].

Соотношение ионов $\mathrm{Mg} / \mathrm{Cl} \sim 0,2$ в полигональножильных льдах характерно как для распространенных на высоких гипсометрических уровнях м. Марре-Сале, p. Юрибей, м. Кареповский (10...30 м), так и в пределах низких гипсометрических уровней рельефа (до $5 \ldots 6$ м) в верхней части разреза о. Белый, о. Сибирякова, разрезах Д-2-09 и Д-3-09 (голоценовый жильный лёд), а также выявлено для морского льда. В первом случае это соотношение, вероятно, связано с поступлением морских аэрозолей, сорбированных снегом, во втором - с заливанием морскими водами полигональной поверхности с морозобойными трещинами и частичным протаиванием ледяных жил [8].

Гидрохимический состав полигонально-жильных льдов в районах 03. Сохонто, пос. Диксон (древний жильный лёд на склоне, разрез Д-1-09), м. МарреСале (из льда жилы на контакте с породой МС-2-09) отличается относительно повышенной минерализацией (36...140 мг/л, при среднем значении 84 мг/л), сульфатно-хлоридно-гидрокарбонатным и смешанным катионным составом (рис. 3, группа 2). Отношение ионов натрия к хлориду не имеет явно выраженной тенденции, что, вероятно, связано со смешанным 
источником. Такой состав мог быть сформирован талыми снеговыми водами с примесью пыли и аэрозолей континентального происхождения [3], а также участием сегрегационного льдообразования при формировании полигонально-жильного льда с многочисленными минеральными вертикальными прожилками.

По составу легкорастворимых солей водные вытяжки из многолетнемерзлых пород, вмещающих ледяные жилы (MC-2A-11), сульфатногидрокарбонатные и сульфатно-хлоридные, натриевые. В отложениях засоленность варьируется от $0,01 \%$ на глубине 1,4 м до 0,21 \% на глубине 3,5 м. При этом на глубине 7 м засоленность понижается до 0,08 \%. Уменьшение засоленности и хлоридов сверху вниз по разрезу и сульфатный состав солей характерны для вторично промерзших отложений таликов [5]. Минерализация полигонально-жильных льдов в этом разрезе (10...88 мг/л, при среднем значении 39 мг/л) не соответствует составу и засоленности вмещающих пород. Засоленность многолетнемёрзлых отложений разрезов о. Белый, пос. Диксон также не отражается на минерализации ультрапресных и пресных сингенетических полигонально-жильных льдов.

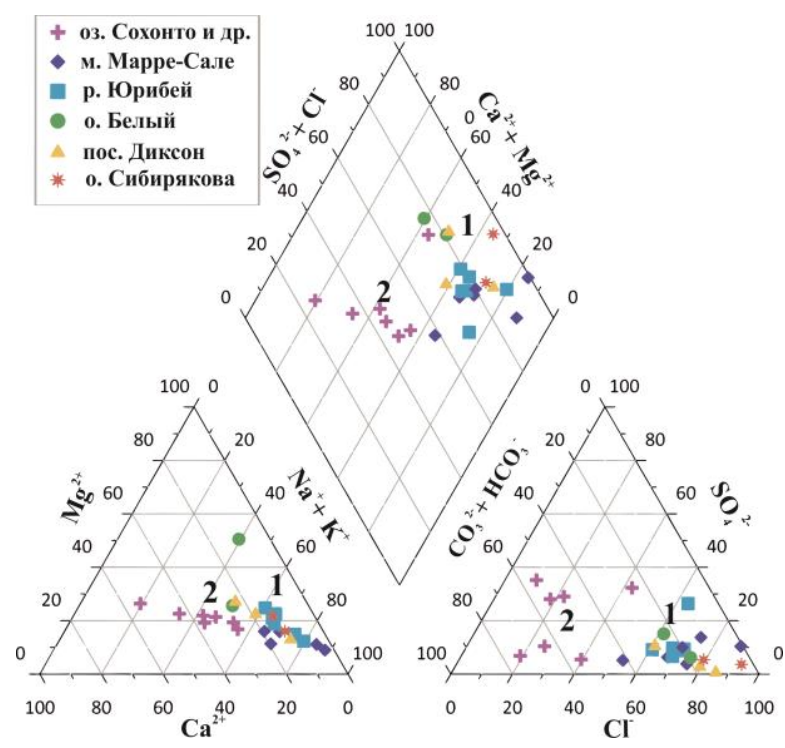

Pис 3. Диаграмма Пайпера химического состава расплавов полигонально-жильных льдов, выраженная в \%-эквивалентах: 1 - группа льдов, сформированных при участии морских аэрозолей; 2 группа льдов, сформированных при участии аэрозолей континентального происхождения $u$ сегрегачионного льдообразования

Fig. 3. Piper diagram. Chemical composition of polygonal ice wedge melts, in \%-equivalents: 1 - group of ice formed with the marine aerosols participation; 2 group of ice formed with the continental origin aerosols and segregation ice formation participation

На диаграмме гидрохимического состава пробы льда из изученных жил попадают в две разные группы по соотношению основных ионов (рис. 3). Это связано с тем, что в формировании льда жил участвовали разные источники влаги, в группе 1 - атмосфер- ные зимние осадки с морскими аэрозолями, в группе 2 - зимние осадки и континентальными аэрозолями вместе с поверхностными водами.

Сезонные льды и поверхностные воды отличаются по гидрохимическому составу от полигональножильного льда. Морской лед наследует минерализацию морской воды, среднесоленый $(1,1 \ldots 3,5$ г/л), характеризуется хлоридным, магниево-натриевым составом (рис. 4). Озерный лед ультрапресный, минерализация уменьшается с глубиной, от 23 мг/л на поверхности до 4 мг/л на глубине. С глубиной меняется катионно-анионный состав от сульфатно-хлоридного, натриевого на поверхности, к гидрокарбонатнохлоридному и смешанному катионному составу на глубине 0,55 м. Такое распределение отражает сезонное изменение гидрохимического состава при ледоставе и повышение концентрации морских аэрозолей в снеге, перекрывающем озерный лед в осеннезимний период, т. к. не вся акватория моря покрыта льдом [17]. Фирновый лед полярного Урала имеет очень низкую минерализацию (1 мг/л), что делает затруднительным количественную оценку его гидрохимического состава, и в отличие от атмосферных осадков изученных ключевых участков [14], в нем отсутствуют примеси морского аэрозоля. Поверхностные воды озер, ручья ультрапресные (27-54 мг/л) по минерализации и имеют хлоридногидрокарбонатный и смешанный катионный состав, что обусловлено двумя источниками формирования атмосферными осадками и обменными процессами с породами в открытой системе.

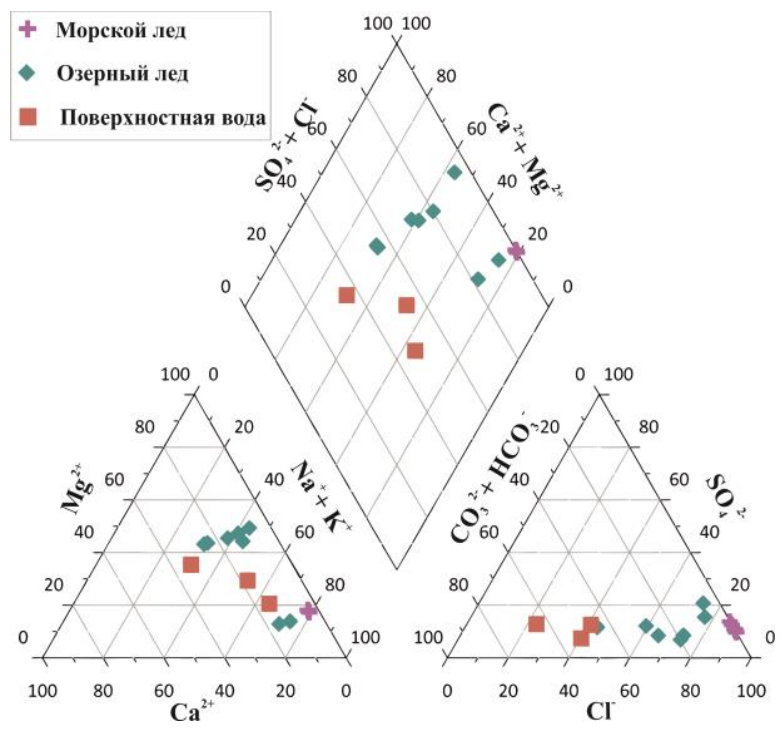

Pис 4. Диаграмма Пайпера химического состава расплавов сезонного льда и поверхностных вод, выраженная в \%-эквивалентах

Fig. 4. Piper diagram. Chemical composition of seasonal ice melt and surface water, in \% equivalents

Из распределения проб на диаграмме следует, что морской и озерный лед по составу ионов сходен с полигонально-жильным льдом группы 1; поверхност- 
ные воды схожи с полигонально-жильным льдом группы 2.

При формировании полигонально-жильных льдов за счет морозобойного растрескивания в начале снеготаяния происходит затекание в трещины и быстрое промерзание талой воды, что сохраняет наиболее близкий к источнику химический состав. Морской атмосферный аэрозоль формирует хлориднонатриевый состав льдов, континентальные аэрозоли гидрокарбонатно-кальциевый состав. В формировании полигонально-жильного льда с многочисленными вертикальными прожилками минеральных частиц вместе с сингенетическим участвовало сегрегационное льдовыделение. В этом случае в летние сезоны в ледяных жилах возникали полости протаивания, в них затекали минеральные грунты вместе с надмерзлотными водами, которые являются источником повышенного содержания водорастворимых солей. При промерзании водонасыщенных грунтов, смешанных с водой оттаявших частей жилы, в замкнутом объеме происходила сегрегация, медленное выделение шлиров грунта и льда и метаморфизация химического состава льда.

\section{Распределение редкоземельных элементов}

Для полигонально-жильных льдов первой и второй группы выявлено превышение кларковых чисел лантаноидов [22] в водорастворимой форме. В полигонально-жильном льду значения концентраций лантаноидов в элементарной жилке разреза МC-2-09 в 70 раз превышают кларковые числа. Превышения выявлены в разрезах: м Кареповский в 30 раз; о. Белый, м. Марре-Сале (разрез МС-2-09 за исключение элементарной жилки) в 10 раз; р. Юрибей и м. МарреСале МС-2А-11 - в 5 раз; оз. Сохонто, о. Сибирякова и пос. Диксон - в 2...4 раза. Содержание РЗЭ в аэрозоле иногда связывают с выветриванием коренных пород [33]. Высокое содержание РЗЭ было обнаружено в талой воде ледников западной Гренландии [34]. Возможно, источником химических элементов являются вулканические выбросы, сорбированные падающим снегом [35]. Накопление лантаноидов в водорастворимой форме обусловлено низкой соленостью жил, т. к. при достижении концентрации солей 6 г/л происходит сорбция легких элементов из раствора [18].

Во взвеси изо льда разрезов МС-2А-11 и р. Юрибей содержания лантаноидов оказались ниже, чем кларковые значения. В верхней части озерного льда, гидрохимический состав которого связан с морскими аэрозолями, в диапазоне глубин $0 \ldots 0,32$ м кларковые значения превышает La в 15 раз и Еu в 2 раза, суммарная концентрация лантаноидов равна 0,92 мкг/л, без лантана - 0,14 мкг/л. В нижней части гидрохимический состав льда формируется озерной водой, в диапазоне глубин 0,32...0,55 м кларковые значения превышает La в 13 ра3, суммарная концентрация лантаноидов равна 0,69 мкг/л, без лантана - 0,05 мкг/л. Повышенное содержание РЗЭ в верхней части озерного льда, сформированного с участием зимних атмо- сферных осадков, обусловлено содержанием лантаноидов в морском аэрозоле. В морском льду кларковые значения превышает La более чем в 100 раз и Eu в 3 раза, средняя суммарная концентрация лантаноидов в образце равна 9,1 мкг/л, без лантана - всего 0,07 мкг/л. Содержание лантана на два порядка превышает содержание остальных лантаноидов. В фирновом льду ледника Романтиков содержание лантаноидов крайне мало (на пределе обнаружения или ниже) - 0,03 мкг/л, без лантана - менее 0,01 мкг/л. Вероятно, низкие концентрации РЗЭ обусловлены отсутствием морского аэрозоля в составе снега Полярного Урала.

В полигонально-жильных льдах содержание лантана равно $20 \%$ от общего содержания лантаноидов. Для разрезов оз. Сохонто содержание лантана выше $50 \%$, МС-2-09 - 30 \% (группа 1). В морском льду лантана содержится 99 \%, в озерном - 88 \%, в фирновом - $77 \%$ от общего содержания лантаноидов. В многолетнемерзлых отложениях МC-2A-11 подвижная форма лантана относительно суммы лантаноидов варьируется от $5 \%$ на глубине 7 м до $63 \%$ на глубине 3 м, где обнаружено засоление. Для взвеси разрезов МС-2А-11 и р. Юрибей обнаружена линейная зависимость валового содержания лантана и суммы лантаноидов, содержание лантана относительно суммы лантаноидов равно 78 \%. При формировании полигонально-жильных льдов наследуется исходный состав РЗЭ от зимних атмосферных осадков. Перераспределение РЗЭ обусловлено частичным протаиванием жил, участием сегрегационного льдообразования и химическим взаимодействием с вмещающими отложениями.

По цериевой и европиевой диаграмме можно определить уровень влияния морских источников РЗЭ, поступавших с аэрозолями, участие окислительных процессов при формировании ледяных жил. Цериевая аномалия, равная единице, означает отсутствие морского источника, а чем ближе к нулю, тем сильнее влияние морских источников РЗЭ. Полигональножильные льды на диаграмме по оси $\mathrm{Ce}_{\text {an }}$ находятся в диапазоне $0,2 \ldots 1,0$; по оси $\mathrm{Eu}_{\text {an }}$ в диапазоне 0,7..1,5 (рис. 5). Полигонально-жильные льды имеют смешанный источник РЗЭ, снеговые талые воды и морские аэрозоли.

Фирновый лед, источником которого является снег, характеризуется отрицательной цериевой аномалией. Количество РЗЭ при этом близко к пределу обнаружения, что затрудняет интерпретацию результатов. Цериевая аномалия морского и озерного льда отрицательная, вероятно, это связано с поступлением Р3Э из морских аэрозолей. Отложения МС-2А-11 имеют отрицательную цериевую аномалию и морской источник РЗЭ. Взвеси из льда разрезов р. Юрибей и MC-2A-11 по цериевой аномалии близки к полигонально-жильному льду.

Европиевая аномалия показывает участие кислорода в процессе льдообразования. Небольшие повышения европиевой аномалии до 1,5 выявлены для разрезов оз. Сохонто и МС-2A-11, это связано с ча- 
стичным протаиванием жил. В целом полигональножильные льды и взвеси распложены на одной линии, близкой к единице. Следовательно, отсутствовали окислительные процессы, и протаивание ледяных жил не происходило. Отмеченные в многолетнемерзлых отложениях положительные европиевые аномалии свидетельствуют о процессах дальнейшего преобразования. В отложениях, вмещающих ледяную жилу (МС-2А-11), происходило преобразование осадочных пород при хорошей аэрации [10], что было возможно только в их талом состоянии и подтверждает их промерзание в талике [5].

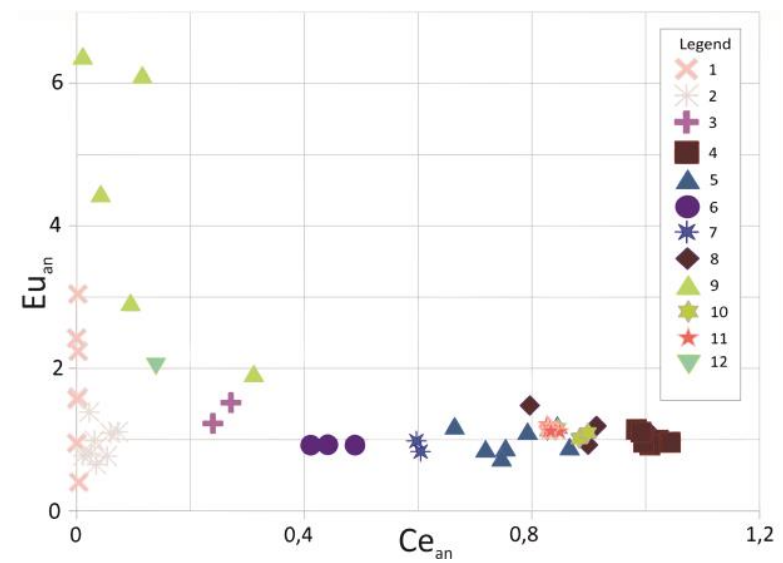

Pис. 5. Диаграмма цериевой и европиевой аномалии: 1 морской лед; 2 - озерный лед; 3-8-полигонально жильный лед; 3 - оз. Сохонто; 4 - р. Юрибей; 5 - о. Бельй, пос. Диксон, м. Кареповский; 6 МC-2-09; 7 - о. Сибирякова; 8 - МC-2A-11; 9 отложения МС-2A-11; 10 - взвесь из льда МС-2A-11; 11 - взвесь из льда района р. Юрибей; 12 - ледник Романтиков

Fig. 5. Diagram of cerium and europium anomalies: 1 sea ice; 2 -lake ice; 3-8-polygonal ice wedge; 3 lake Sokhonto; 4 - river Yuribey; 5 - island Bely, settlement Dikson, cape Karepovskiy; 6 - MS-2-09; 7 - Sibiryakova island; 8 -MS-2A-11; 9 - soils of $M S-2 A-11$ section; 10 - ice suspension of $M S-2 A-11$ section; 11 - ice suspension of the river Yuribey area; 12 - glacier Romantikov

Соотношение легких и тяжелых РЗЭ отражает процессы перехода элементов из растворенной в нерастворенную форму. Диаграмма принимает вид степенной функции и отражает условия льдообразования - наличие термодинамического геохимического барьера при образовании полигонально-жильных льдов (рис. 6). При морозобойном растрескивании талая снеговая вода сразу после попадания в трещину замерзает, формируя жилу, - данный процесс минимизирует перераспределение РЗЭ, источником которых являются атмосферные осадки. Для полигонально-жильных льдов и взвеси из льда соотношение легких и тяжелых РЗЭ не превышает 1,7 при среднем значении 0,9. Следовательно, отсутствовало перераспределение Р3Э при формировании льда, происходило быстрое промерзание воды без контакта с вмещающими отложениями. Таким образом, соотношение легких и тяжелых элементов, близкое к единице, яв- ляется показателем, характеризующим полигональножильный лед. Для сезонных льдов соотношение легких и тяжелых РЗЭ не ниже - 1,9, при среднем значении 19,6. Для отложений разреза МС-2А-2011 льдов легких и тяжелых РЗЭ не ниже 1,7 при среднем значении 6,3, следовательно, многолетнемерзлые отложения обогащены легкими элементами. Источником легких элементов могут служить морские и речные поверхностные воды, обогащенные РЗЭ вследствие терригенного стока - поступления с суши растворенных, коллоидных и взвешенных веществ. При смешении вод происходил переход водорастворимых легких РЗЭ в нерастворимую форму [18].

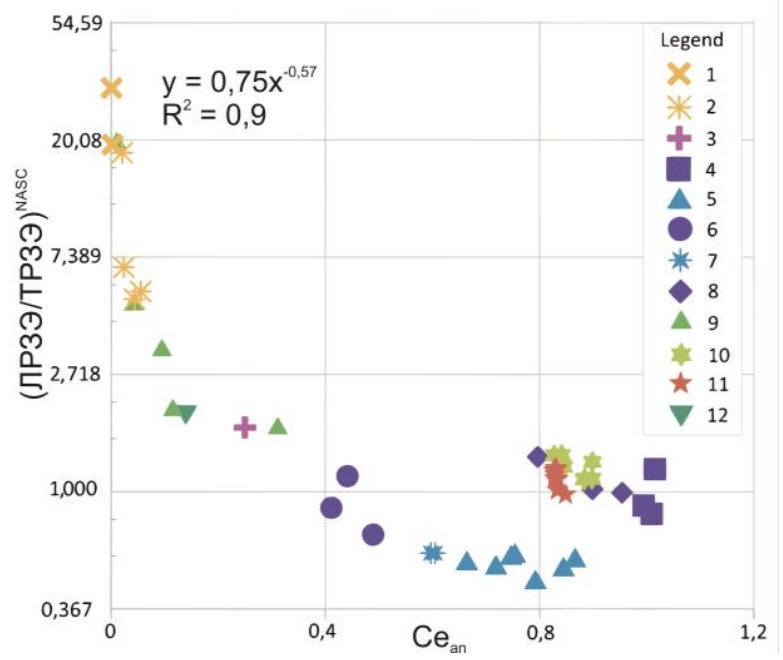

Рис 6. Диаграмма соотношения цериевой аномалии и соотношения легких и тяжелых элементов: 1 морской лед; 2 - озерный лед; 3-8-полигонально жильный лед; 3 - оз. Сохонто; 4 - р. Юрибей; 5 - о. Бельй, пос. Диксон, м. Кареповский; 6 м. Марре-Сале - МС-2-09; 7 - о. Сибирякова; 8 МC-2A-11; 9 - отложения $M C-2 A-11 ; 10$ - взвесь из льда разреза $M C-2 A-11 ; 11$ - взвесь из льда района р. Юрибей; 12 -ледник Романтиков

Fig. 6. Diagram of cerium anomaly ratio and light and heavy elements ratio: 1 - sea ice; 2 - lake ice; 3-8polygonal ice wedge; 3 -lake Sokhonto; 4 -river Yuribey; 5 - island Bely, settlement Dikson, cape Karepovskiy; 6 - MS-2-09; 7 - Sibiryakova island; 8-MS-2A-11; 9 - soils of MS-2A-11 section; $10-$ ice suspension of MS-2A-11 section; 11 - ice suspension of the river Yuribey area; 12 - glacier Romantikov

Несмотря на различия в гидрохимическом составе, полигонально-жильные льды 1 и 2 группы имеют общий источник редкоземельных элементов - зимние атмосферные осадки и морской аэрозоль. Протаивание жил и незначительный обмен РЗЭ с вмещающими отложениями обнаружен только для разрезов МС-2А-11 (группа 1) и оз. Сохонто (группа 2).

Распределение нормированных содержаний РЗЭ для полигонально-жильных льдов, вмещающих отложений и взвеси из льда разреза МС-2А-11 представлено на рис. 7. Максимальные содержания РЗЭ во взвеси из льда находятся на глубине 3,5-3,7 м, во 
льду на глубине 1,8 м. Несмотря на изменение концентраций РЗЭ в образцах закономерность распределения остается неизменной. Следовательно, условия и источники РЗЭ не менялись в процессе формирования.

Распределение нормированных содержаний РЗЭ для сезонных льдов представлено на рис. 8. В озер- ном льду содержание РЗЭ и минерализация (с 22 до 5 мг/л) уменьшается с глубиной, т. к. верхняя часть льда сформирована в основном за счет снега. Для морского льда данная тенденция менее выражена. На диаграмме видно высокое содержание лантана, источником которого является терригенный материал, поставляемый реками [18].

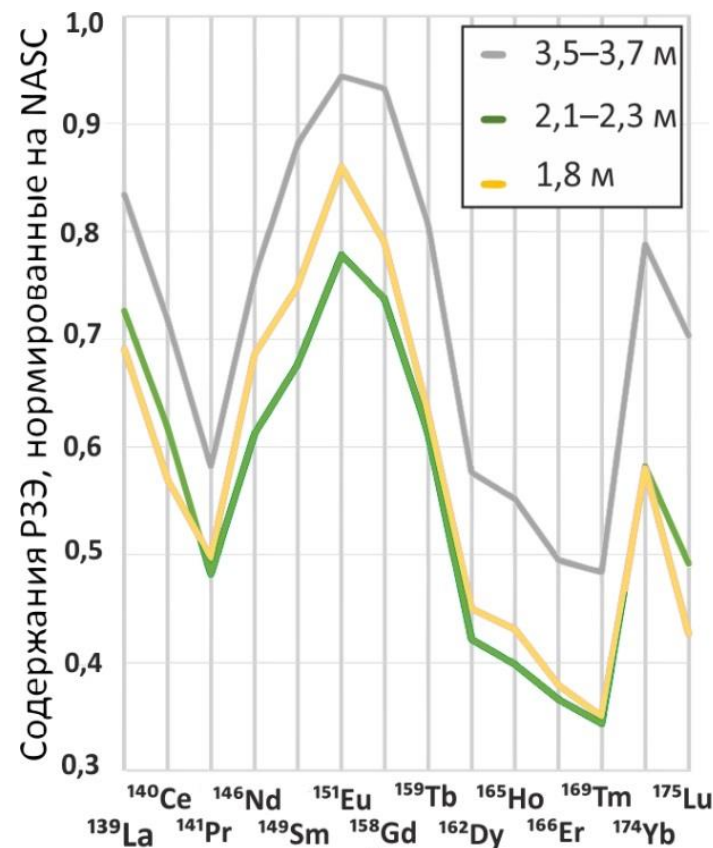

a)

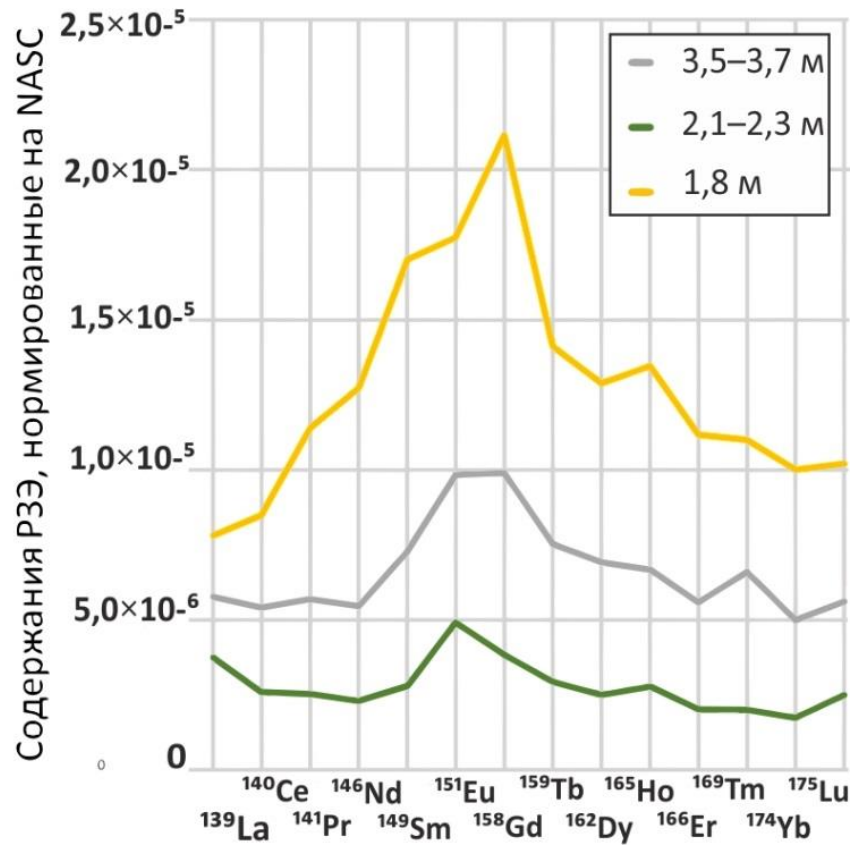

b)

Рис 7. Распределение нормированных содержаний РЗЭ разреза МC-2A-11 для: а) взвеси из льда; b) полигональножильных льдов

Fig 7. Distribution of normalized REE contents of MS-2A-11 section for: (a) ice suspensions; (b) polygonal ice wedge

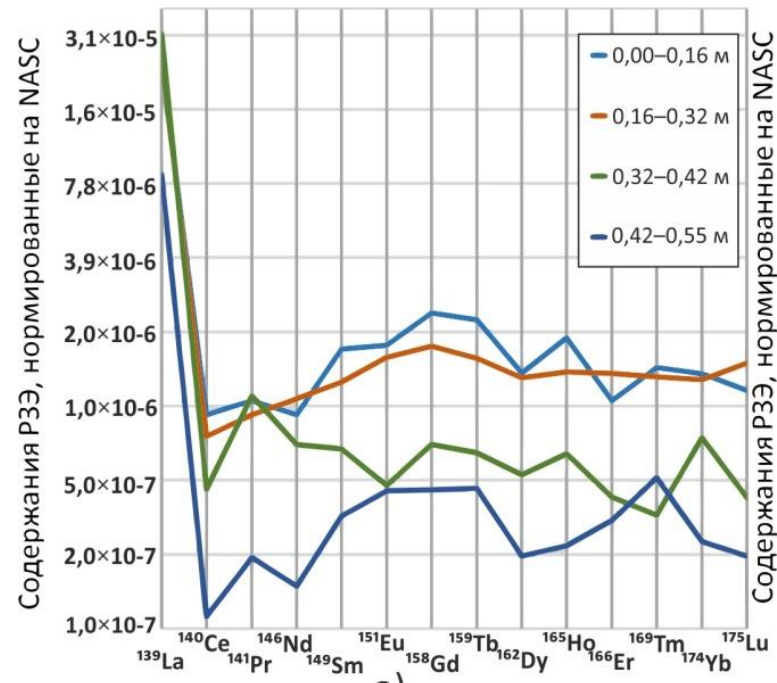

a)

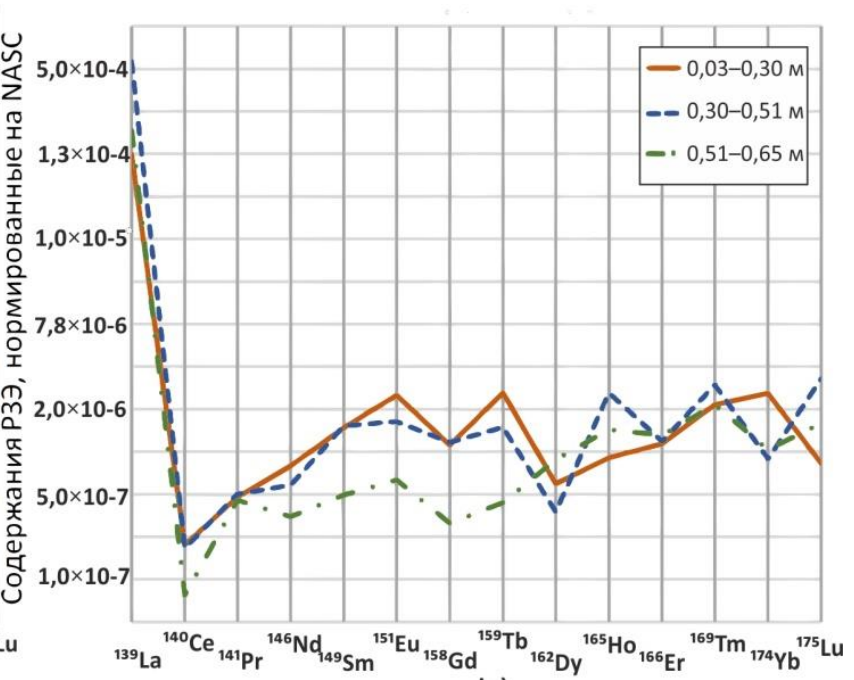

b)

Рис 8. Распределение нормированных (NASC) содержаний РЗЭ в сезонных льдах: а) озерный лёд; b) морской лёд

Fig 8. Distribution of normalized REE contents in seasonal ice: a) lake ice; b) sea ice

Р3Э могут находиться в коллоидной составляющей с железом [18]. Зависимость суммарной концентрации лантаноидов и содержания железа, иттрия и тория прослеживается для полигонально-жильных льдов, за исключением современной элементарной жилки MC-2-09 и голоценовой жилы м. Кареповский. Источником железа в полигонально-жильных льдах могут являться аэрозоли и атмосферные осадки [32]. Корреляция суммарной концентрации лантаноидов и валового содержания железа, фосфора, тория, иттрия 
и урана для взвеси из льда разрезов МС-2А-2011, р. Юрибей может указывать на то, что во взвеси присутствует в небольших количествах минерал, содержащий эти элементы, например, монацит. Монацит широко распространен как акцессорный минерал в гранитных изверженных и гнейсовых метаморфических породах, и наносные пески в областях с такими породами могут содержать монацит [36].

Полигонально-жильный лед современной элементарной жилки MC-2-09 и голоценовой жилы м. Кареповский по распределениям РЗЭ не имеет достоверных линейных корреляций с другими полигональножильными льдами, возможно, высокие содержания РЗЭ в этих льдах обусловлены участием стока насыщенных органическими веществами вод и современным формированием их химического состава, в котором отражено влияние антропогенных источников РЗЭ.

\section{Выводы}

Сравнительный анализ гидрохимического состава и распределения редкоземельных элементов в полигонально-жильных льдах выявил:

1. На химический состав полигонально-жильных льдов, изученных в прибрежной зоне ключевых участков о. Белый, о. Сибирякова, Западного Ямала и Западного Таймыра, имели влияние морские и континентальные аэрозоли. Сингенетические полигонально-жильные льды, пресные и ультрапресные по минерализации, сформированы при промерзании талых вод, содержат сорбированные снегом морские аэрозоли. Полигонально-жильные льды в удаленном от моря районе оз. Сохонто не имеют признаков морского влияния по соотношению основных ионов. Полигонально-жильные льды с минеральными включениями формировались не только за счет талых снеговых вод с аэрозолями континентального происхождения, но и за счет надмерзлотных вод.

2. Минерализация сингенетических полигональножильных льдов без участия сегрегационного

\section{СПИСОК ЛИТЕРАТУРЫ}

1. Кирюхин В.А., Коротков А.И., Павлов А.Н. Общая гидрогеология. - Л.: Недра, 1988. - 359 с.

2. Методы геокриологических исследований / под ред. Э.Д. Ершова. - М.: МГУ им. М.В. Ломоносова, 2004. - 511 с.

3. Фотиев С.М. Закономерности формирования ионно-солевого состава природных вод Ямала // Криосфера Земли. - 1999. T. III. - № 2. - C. 40-65.

4. Анисимова Н.П. Криогидрохимические особенности мерзлой зоны. - Новосибирск: Наука, 1981. - 150 с.

5. Крицук Л.Н. Подземные льды Западной Сибири. - М.: Научный мир, 2010. - 352 с.

6. Подземные льды в четвертичных отложениях побережья Карского моря как отражение палеогеографических условий конца неоплейстоцена-голоцена / И.Д. Стрелецкая, Е.А. Гусев, А.А. Васильев, П.В. Рекант, Х.А. Арсланов // Бюллетень комиссии по изучению четвертичного периода. - 2012. - № 72. С. 28-59.

7. Васильчук Ю.К., Трофимов В.Т. О находках сильноминерализованных повторно-жильных льдов // Известия Академии наук СССР. Серия геологическая. - 1984. - № 8. - С. 129-134.

8. Колебания уровня моря и их отражение в составе и строении полигонально-жильных льдов в низовьях Енисея / О.Л. Опокина, Е.А. Слагода, И.В. Томберг, М.Ю. Суслова, А.Д. Фирсо- льдообразования не зависит от степени засолённости вмещающих отложений.

3. Морской лед наследует минерализацию и состав морской воды. Озерный лед различается по глубине и отражает сезонное изменение гидрохимического состава при ледоставе и повышение концентрации морских аэрозолей в снеге, перекрывающем озерный лед. Фирновый лед полярного Урала имеет очень низкую минерализацию, в нем отсутствуют примеси морского аэрозоля.

4. Зимние атмосферные осадки имеют в своем составе атмосферные аэрозоли, насыщенные редкоземельными элементами.

5. В полигонально-жильных льдах выявлено увеличение содержаний лантаноидов в водорастворимой форме по сравнению с кларковыми значениями и современными поверхностными льдами. По цериевой аномалии в большинстве изученных сингенетических ледяных жил подтверждается участие морских аэрозолей. По распределениям редкоземельных элементов выявлено характерное для полигонально-жильных льдов соотношение легких и тяжелых редкоземельных элементов, равное 0,9 , и отношение лантана к остальным лантаноидам, равное 0,2 .

6. В полигонально-жильных льдах голоценового и неоплейстоценового возраста реализован природный механизм накопления редкоземельных элементов в водорастворимой форме в комплексе с железом, торием и иттрием. Вытаивание ледяных жил может приводить к поступлению редкоземельных элементов в поверхностные воды.

Работа выполнена по госзаданию НИР ТюмНЦ СО РАН на 2018-2020 годы, протокол № 2 от 08.12.2017 г. Проект IX.133.1.2: Закономерности стадийных изменений мерзлых толш, льдов и ландшафтов арктических островов и обрамления Карского моря под воздействием климата, экзогенных и эндогенных геологических проиессов. Аналитические исследования выполнены при поддержке РФФИ № 18-05-60222 Арктика, № 18-55-11005 AF_t, № 18-05-00376 A.

ва, Т.В. Ходжер, Н.А. Жученко // Лёд и Снег. - 2014. № 2 (126). - С. 82-90.

9. Алексеева Л.П. Геохимия подземных льдов, соленых вод и рассолов Западной Якутии: дис. ... д-ра геол.-минерал. наук. Иркутск, 2015. - 223 с.

10. Иванова В.В. Геохимия пластовых льдов острова Новая Сибирь (Новосибирские острова, Российская Арктика) как отражение условий их генезиса // Криосфера Земли. - 2012. T. XVI. - № 1. - C. 56-70.

11. Соломатин В.И. Геокриология: подземные льды. 2 изд., испр. и доп. - М.: Изд-во Юрайт, 2017. - 346 с.

12. Рогов В.В. Основы криогенеза. - Новосибирск: Гео, 2009. $203 \mathrm{c}$.

13. Бутаков В.И., Тихонравова Я.В., Слагода Е.А. Закономерности формирования геохимического состава подземных льдов и отложений на севере полуострова Гыдан // Известия высших учебных заведений. Нефть и газ. - 2018. - № 5 (131). - С. 30-40.

14. Исследования атмосферного аэрозоля в арктических районах России / Л.П. Голобокова, В.В. Полькин, Д.М. Кабанов, С.А. Терпугова, Д.Г. Чернов, Е.В. Чипанина, Т.В. Ходжер, О.Г. Нецветаева, М.В. Панченко, С.М. Сакерин // Лед и снег. 2013. - Т. 53. - № 2. - С. 129-136.

15. Дэвис Дж.С. Статистический анализ в геологии. - М.: Недра, 1990. $-319 \mathrm{c}$ 
16. Васильчук Ю.К. Геохимический состав подземных льдов севера Российской Арктики // Арктика и Антарктика. 2016. - № 2. - C. 99-115.

17. Variability of Water Chemistry in Tundra Lakes, Petuniabukta Coast, Central Spitsbergen, Svalbard / M. Mazurek, R. Paluszkiewicz, G. Rachlewicz, Z. Zwoli'nski // The Scientific World Journal. - 2012. - Article ID 596516. - 13 p.

18. Дубинин А.В. Геохимия редкоземельных элементов в океане // Литология и полез. ископаемые. - 2004. - № 4. - С. 339-358.

19. Piper D.Z., Bau M. Normalized rare earth elements in water, sediments, and wine: identifying sources and environmental redox conditions // American Journal of Analytical Chemistry. - 2013. V. 4. - P. 69-83.

20. Строение и генезис подземных льдов в верхненеоплейстоценголоценовых отложениях мыса Марре-Сале (Западный Ямал) Е.А. Слагода, О.Л. Опокина, В.В. Рогов, А.Н. Курчатова // Криосфера Земли. - 2012. - Т. 16. - № 2. - С. 9-23.

21. Alexeev S.V., Alexeeva L.P., Kononov A.M. Trace elements and rare earth elements in ground ice in kimberlites and sedimentary rocks of Western Yakutia // Cold Regions Science and Technology. - 2016. - T. 123. - C. 140-148.

22. Справочник по геохимическим поискам полезных ископаемых / под ред. А.П. Соловова. - М.: Недра, 1990. - 335 с.

23. Elderfield H. The oceanic chemistry of the rare earth elements // Phil. Trans. R. Soc. London A. - 1988. - V. 325. - P. 105-126.

24. Johannesson K.H., Stetzenbach K.J., Hodge V.F. Rare earth elements as geochemical tracers of regional groundwater mixing // Geochim. Cosmochim. Acta. - 1997. - V. 61. - № 17. - P. 3605-3618.

25. Rare earth element distribution in the Lake Tyrrell groundwaters, Victoria, Australia / J.A. Fee, H.E. Gaudette, W.B. Lyons, D.T. Long // Chem. Geol. - 1992. - V. 96. - P. 67-93.

26. Rare earth elements in chloride-rich groundwater, Palo Duro Basin, Texas, USA / D.G. Gosselin, M.R. Smith, E.A. Lepel, J.C. Laul // Geochim. Cosmochim. Acta. - 1992. - V. 56. - P. 1495-1505.

27. The «North American shale composite»: its compilation, major and trace element characteristics / L.P. Gromet, R.F. Dymek, L.A. Haskin, R.L. Korotev // Geochim. Cosmochim. Acta. 1984. - V. 48. - № 12. - P. 2469-2482.
28. Rare earth element variations in Mid-Archean banded iron formations: implications for the chemistry of ocean and continent and plate tectonics / Y. Kato, I. Ohta, T. Tsunematsu et al. // Geochim. Cosmochim. Acta. - 1998. - V. 62. - № 21/22. P. 3475-3497.

29. Геокриология СССР. Западная Сибирь / под ред. Э.Д. Ершова. М.: Недра, 1989. - 454 c.

30. Радиоуглеродное датирование многолетнемерзлых отложений острова Белый, Карское море / Е.А. Слагода, Г.В. Симонова, Я.В. Тихонравова, А.О. Кузнецова, К.А. Попов, П.Т. Орехов // Криосфера Земли. - 2018. - Т. 22. - № 4. - С. 3-14.

31. Реконструкция развития термокарста в районе озера Сохонто (Центральный Ямал) в позднем неоплейстоцене-голоцене по криолитологическим и ботаническим данным / Е.А. Слагода, М.В. Нарушко, Ю.И. Прейс, О.Л. Опокина, А.Н. Курчатова // Криосфера Земли. - 2016. - Т. 20. - № 4. - С. 59-68.

32. Семенец Е.С., Свистов П.Ф., Талаш А.С. Химический состав атмосферных осадков. Российского Заполярья // Известия Томского политехнического университета. Инжиниринг георесурсов. - 2017. - Т. 328. - № 3. - С. 27-36.

33. Water-soluble trace, rare earth elements and organic compounds in Arctic aerosol / C. Turetta, R. Zangrando, E. Barbaro, J. Gabrieli, E. Scalabrin, P. Zennaro, A. Gambaro, G. Toscano, C. Barbante // Rendiconti Lincei. Scienze Fisiche e Naturali. - 2016. - V. 27. P. 95-103.

34. Ocean circulation and freshwater pathways in the Arctic Mediterranean based on a combined Nd isotope, REE and oxygen isotope section across Fram Strait / G. Laukert, M. Frank, D. Bauch et al. // Geochimica et Cosmochimica Acta. - 2017. V. 202. - P. 285-309.

35. Sadeghi M. et al. REE contents in solid sample media and stream water from different geological contexts: Comparison between Italy and Sweden // Journal of Geochemical Exploration. - 2013. V. 133. - P. 176-201.

36. Harlov D.E. et al. Apatite-monazite relations in the Kiirunavaara magnetite-apatite ore, northern Sweden // Chemical Geology. 2002. - V. 191. - P. 47-72.

Поступила 14.11.2019 2.

\section{Информация об авторах}

Бутаков В.И., ассистент-стажер Института геологии и нефтегазодобычи Тюменского индустриального университета; инженер 1 категории НИПИ «Нефтегазпроект» Тюменского индустриального университета.

$\boldsymbol{C л а z о д а ~} \boldsymbol{E} . \boldsymbol{A}$., доктор геолого-минералогических наук, главный научный сотрудник лаборатории Комплексных методов изучения криогенных геосистем Института криосферы Земли ТюмНЦ СО РАН; ведущий научный сотрудник, Тюменский государственный университет; ведущий научный сотрудник, Тюменский индустриальный университет.

Tихонравова Я.B., научный сотрудник лаборатории Общей геокриологии Института мерзлотоведения им. П.И. Мельникова СО РАН; научный сотрудник лаборатории Комплексных методов изучения криогенных геосистем Института криосферы Земли ТюмНЦ СО РАН.

Опокина О.Л., кандидат геолого-минералогических наук, старший научный сотрудник лаборатории Комплексных методов изучения криогенных геосистем Института криосферы Земли ТюмНЦ СО РАН; доцент, Тюменский индустриальный университет.

Томберг И.В., кандидат географических наук, научный сотрудник лаборатории Гидрохимии и химии атмосферы Лимнологического института СО РАН.

Жученко Н.А., научный сотрудник лаборатории Гидрохимии и химии атмосферы Лимнологического института СO PAH. 
UDC 551.34:502.6:550.46

\section{HYDROCHEMICAL COMPOSITION AND RARE-EARTH ELEMENTS IN ICE WEDGE OF THE KARA REGION CRYOLITOZONE KEY AREAS}

\author{
Vladislav I. Butakov 1 , \\ vladbutakov@yahoo.com
Elena A. Slagoda $2,3,1$, eslagoda@ikz.ru \\ Yana V. Tikhonravova4,2, \\ tikh-jana@yandex.ru
}

\author{
Olga L. Opokina ${ }^{2,1}$, \\ opokina@ikz.ru \\ Irina V. Tomberg ${ }^{5}$, \\ kaktus@lin.irk.ru
} Natalja A. Zhuchenko5,
zhna@lin.irk.ru

1 Tyumen Industrial University,

38, Volodarsky street, Tyumen, 625000, Russia.

2 Earth Cryosphere Institute, Tyumen Scientific Centre SB RAS, 86 , Malygin street, Tyumen, 625000, Russia.

3 University of Tyumen,

6, Volodarsky street, Tyumen, 625003, Russia.

4 Melnikov Permafrost Institute SB RAS,

36, Merzlotnaya street, Yakutsk, 677010, Russia

5 Limnological Institute SB RAS,

3, Ulan-Bator street, Irkutsk, 664033, Russia.

Relevance of the research. Information on composition, ice content and geochemical characteristics of frozen rocks is necessary for exploration of oil and gas condensate fields of Yamal, Gydan and Taimyr. Among the factors determining the tundra landscapes ecology of the cryolithozone, underground ice and their melting have great importance. The hydrochemical composition and rare-earth elements content in syngenetic ice wedge retain the information on the moisture sources and conditions of their formation. The main ions correlation and rare-earth elements distribution in the ice composition can be used to estimate the influence of such natural factors as precipitation, sea and volcanic aerosols and anthropogenic pollution.

The main aim of the research is to identify chemical elements sources and to assess the impact of the ice type on hydrochemical composition and rare-earth elements distribution in different genetic types of ice - wedge, seasonal and firn ice.

Objects: ice wedge, sediments rocks, seasonal ice, surface water, taken in expeditions Earth Cryosphere Institute, Tyumen scientific centre SB RAS in 2009-2014.

Methods of chemical research: inductively coupled plasma mass spectrometry, atomic absorption spectrometry, emission photometry, chromatography.

Results. It is established that marine and continental aerosols influenced the chemical composition of ice wedge studied in the coastal zone of the key areas of Belyj island, Sibiryakova island, Western Yamal and Western Taimyr. Fresh and ultrafresh syngenetic ice wedge is formed by freezing melt water, which contains snow-sorbed sea aerosols - suspended in the atmosphere solid and liquid particles. Ice wedge in the lake Sokhonto area long-distanced from the sea has no signs of marine influence according to the main ions content. Ice wedge with mineral inclusions was formed not only due to snow melt water with aerosols of continental origin, but also due to the suprapermafrost water. It was found out that lanthanide content in water-soluble form has increased in comparison with both clark values and the content in the modern surface ice. In the most of examined syngenetic ice wedge the participation of marine aerosols is confirmed taking into account the cerium anomaly. Moreover according to the distribution of rare-earth elements the correlation between light and heavy rare-earth elements typical for ice wedge, equal to 0,9, and correlation between lanthanum and the other lanthanides, equal to 0,2, are observed. Sea ice inherits the mineralization and composition of sea water. Lake ice varies in depth and reflects seasonal changes in hydrochemical composition of ice and increases in concentration of marine aerosols in the snow covering the lake ice. Firn ice of the polar Urals has a very low mineralization, there are no impurities of sea aerosol. The natural mechanism of rare earth elements accumulation in water-soluble form in combination with iron, thorium and yttrium is implemented in ice wedge of the Holocene and Neopleistocene. Melting out ice wedge may lead to the flow of rare-earth elements in the surface water.

\section{Key words:}

Ice wedge, ice hydrochemistry, rare-earth elements, geochemistry of deposits, cryogenic concentration, clark of hydrosphere.

The research was carried out by the state task of R\&D Tyumen SC SB RAS for 2018-2020, report no. 2, 08.12.2017. Project IX.133.1.2: Laws of stage changes of permafrost, ice and landscapes of arctic islands and the Kara Sea framing under the impact of climate, environmental and endogen geological processes. The analytical research was supported by the RFBR no. 18-05-60222 Arctic, no. 18-55-11005 AF_t, № 18-05-00376 A. 


\section{REFERENCES}

1. Kiryukhin V.A., Korotkov A.I., Pavlov A.N. Obshchaya gidrogeologiya [Fundamental Hydrogeology]. Leningrad, Nedra Publ., 1988. 359 p.

2. Metody geokriologicheskikh issledovaniy [Methods of geocryological investigations]. Ed. by E.D. Ershov. Moscow, Moscow University Press, 2004. 512 p.

3. Fotiev S.M. Regularities in formation of ionic-salt composition of natural waters, the Yamal Peninsula. Kriosfera zemly, 1999, vol. III, no. 2, pp. 40-65. In Rus.

4. Anisimova N.P. Kriogidrokhimicheskie osobennosti merzloy zony [Cryohydrochemical characteristics of frozen zone]. Novosibirsk, Nauka Publ., 1982. 151 p.

5. Kritsuk L.N. Podzemnye ldy Zapadnoy Sibiry [Ground ice of West Siberia]. Moscow, Nauchny Mir Publ., 2010. 352 p.

6. Streletskaya I.D., Gusev E.A., Vasiliev A.A., Rekant P.V., Arslanov H.A. Ground ice in quaternary deposits of Kara sea coast as a proxy of palaeogeography in late pleistocene-holocene. Byulleten komissii po izucheniyu chetvertichnogo perioda, 2012, no. 72. pp. 28-59. In Rus.

7. Vasilchuk Yu.K., Trofimov V.T. O nakhodkakh silnomineralizovannykh povtorno-zhilnykh ldov [About finding strongly mineralized ice wedge]. Izvestiya AN SSSR. Seriya geologicheskaya, 1984, no. 8, pp. 129-134.

8. Opokina O.L., Slagoda E.A., Tomberg I.V., Suslova M.Yu., Firsova A.D., Hodzher T.V., Zhuchenko N.A. Sea level fluctuations and their signature in the composition and structure of polygonal ice wedge in the Yenisei River lower reaches. Led $i$ Sneg, 2014, no. 2 (126). pp. 82-90. In Rus.

9. Alekseeva L.P. Geokhimiya podzemnykh ldov, solenykh vod $i$ rassolov Zapadnoy Yakutii. Dis. Dokt. nauk [Geochemistry of underground ice, salt water and brines of Western Yakutia. Dr. Diss.]. Irkutsk, 2015. 223 p.

10. Ivanova V.V. Geochemical features of formation of massive ground ice bodies (New Siberia island, Siberian Arctic) as the evidence of their genesis. Kriosfera Zemli, 2012, vol. XVI, no. 1 , pp. 56-70. In Rus.

11. Solomatin V.I. Geokriologiya: podzemnye ldy [Geocryology: underground ice]. Moscow, Yurayt Publ., 2017. 346 p.

12. Rogov V.V. Osnovy kriogeneza [Fundamentals of cryogenesis] Novosibirsk, Geo Publ., 2009. 203 p.

13. Butakov V.I., Tikhonravova Ya.V., Slagoda E.A. Regularities of geochemical composition formation of underground ice and deposits on the north of the Gydan peninsula. Izvestiya vysshikh uchebnykh zavedeniy. Neft i gaz, 2018, no 5 (131), pp. 30-40. In Rus.

14. Golobokova L.P., Polkin V.V., Kabanov D.M., Terpugova S.A., Chernov D.G., Chipanina E.V., Hodzher T.V., Necvetaeva O.G., Panchenko M.V., Sakerin S.M. Atmospheric aerosol research in the Arctic regions of Russia. Led $i$ sneg, 2013, vol. 53, no. 2, pp. 129-136. In Rus.

15. Davis J.C. Statistics and data analysis in geology. Kansas Geological Survey. New York, John Wiley and Sons Publ., 1986. $656 \mathrm{p}$.

16. Vasilchuk Yu.K. Geochemical composition of underground ice in the North of the Russian Arctic. Arktika i Antarktika, 2016, no. 2 , pp. 99-115. Available at: http://e-notabene.ru/arctic/ article_21378.html (accessed 10 November 2019). In Rus.

17. Mazurek M., Paluszkiewicz R., Rachlewicz G., Zwoli'nski Z. Variability of Water Chemistry in Tundra Lakes, Petuniabukta Coast, Central Spitsbergen, Svalbard. The Scientific World Journal, 2012, Article ID 596516. 13 p.

18. Dubinin A.V. Geochemistry of rare earth elements in the ocean. Lithology and Mineral Resources, 2004, vol. 39, no 4. pp. 289-307.

19. Piper D.Z., Bau M. Normalized rare earth elements in water, sediments, and wine: identifying sources and environmental redox conditions. American Journal of Analytical Chemistry, 2013, vol. 4, pp. 69-83.

20. Slagoda E.A., Opokina O.L., Rogov V.V., Kurchatova A.N. Structure and genesis of the underground ice in the neopleistocene-holocene sediments of Marre-Sale cape, Western Yamal. Kriosfera Zemli, 2012, vol. 16, no. 2, pp. 9-23. In Rus.

21. Alexeev S.V., Alexeeva L.P., Kononov A.M. Trace elements and rare earth elements in ground ice in kimberlites and sedimentary rocks of Western Yakutia. Cold Regions Science and Technology, 2016, vol. 123, pp. 140-148.

22. Spravochnik po geokhimicheskim poiskam poleznykh iskopaemykh [Guide to geochemical prospecting for minerals]. Ed. by A.P. Solovov. Moscow, Nedra Publ., 1990. 335 p.

23. Elderfield $\mathrm{H}$. The oceanic chemistry of the rare earth elements. Phil. Trans. R. Soc. London A, 1988, vol. 325, pp. 105-126.

24. Johannesson K.H., Stetzenbach K.J., Hodge V.F. Rare earth elements as geochemical tracers of regional groundwater mixing. Geochim. Cosmochim. Acta, 1997, vol. 61, no. 17, pp. 3605-3618.

25. Fee J.A., Gaudette H.E., Lyons W.B., Long D.T. Rare earth element distribution in the Lake Tyrrell groundwaters, Victoria, Australia. Chem. Geol., 1992, vol. 96, pp. 67-93.

26. Gosselin D.G., Smith M.R., Lepel E.A., Laul J.C. Rare earth elements in chloride-rich groundwater, Palo Duro Basin, Texas, USA. Geochim. Cosmochim. Acta, 1992, vol. 56, pp. 1495-1505.

27. Gromet L.P., Dymek R.F., Haskin L.A., Korotev R.L. The «North American shale composite»: its compilation, major and trace element characteristics. Geochim. Cosmochim. Acta, 1984, vol. 48, no. 12, pp. 2469-2482.

28. Kato Y., Ohta I., Tsunematsu T. Rare earth element variations in Mid-Archean banded iron formations: implications for the chemistry of ocean and continent and plate tectonics. Geochim. Cosmochim. Acta, 1998, vol. 62, no. 21/22, pp. 3475-3497.

29. Geokriologiya SSSR. Zapadnaya Sibir [Geocryology of the USSR. Western Siberia]. Ed. by E.D. Ershov. Moscow, Nedra Publ., 1989. $454 \mathrm{p}$.

30. Slagoda E.A., Simonova G.V., Tikhonravova Ya.V., Kuznetsova A.O., Popov K.A., Orehov P.T. Radiocarbon dating of permafrost in Bely island, the Kara sea. Earth's cryosphere, 2018, vol. 22, no. 4. pp. 3-11.

31. Slagoda E.A., Narushko M.V., Preys Yu.I., Opokina O.L., Kurchatova A.N. Reconstruction of thermokarst in the late pleistocene-holocene from geocryological and botanical data (area of lake Sokhonto, Central Yamal). Kriosfera Zemli, 2016, vol. 20, no. 4, pp. 59-68. In Rus.

32. Semenec E.S., Svistov P.F., Talash A.S. Chemical composition of atmospheric precipitation in Russian Subarctic. Bulletin of the Tomsk Polytechnic University. Geo Assets Engineering, 2017, vol. 328, no. 3, pp. 27-36. In Rus.

33. Turetta C., Zangrando R., Barbaro E., Gabrieli J., Scalabrin E., Zennaro P., Gambaro A., Toscano G., Barbante C. Water-soluble trace, rare earth elements and organic compounds in Arctic aerosol. Rendiconti Lincei. Scienze Fisiche e Naturali, 2016, vol. 27, pp. 95-103.

34. Laukert G., Frank M., Bauch D. Ocean circulation and freshwater pathways in the Arctic Mediterranean based on a combined $\mathrm{Nd}$ isotope, REE and oxygen isotope section across Fram Strait. Geochimica et Cosmochimica Acta, 2017, vol. 202, pp. 285-309.

35. Sadeghi M. REE contents in solid sample media and stream water from different geological contexts: Comparison between Italy and Sweden. Journal of Geochemical Exploration, 2013, vol. 133, pp. 176-201.

36. Harlov D.E. Apatite-monazite relations in the Kiirunavaara magnetite-apatite ore, northern Sweden. Chemical Geology, 2002, vol. 191, pp. 47-72. 
Information about the authors

Vladislav I. Butakov, trainee assistant, engineer $1^{\text {st }}$ category, Tyumen Industrial University.

Elena A. Slagoda, Dr. Sc., principal researcher, Tyumen Scientific Centre SB RAS; leading researcher, University of Tyumen; leading researcher, Tyumen Industrial University.

Yana V. Tikhonravova, researcher, Melnikov Permafrost Institute SB RAS; researcher, Earth Cryosphere Institute, Tyumen Scientific centre SB RAS.

Olga L. Opokina, Cand. Sc., senior researcher, Tyumen Scientific centre SB RAS; associate professor, Tyumen Industrial University.

Irina V. Tomberg, Cand. Sc., researcher, Limnological Institute SB RAS.

Natalja A. Zhuchenko, researcher, Limnological Institute SB RAS. 